\title{
Biological modulation of corneal epithelial wound healing
}

\author{
Modulação biológica do processo de cicatrização epitelial da córnea \\ Renata Ruoco Loureiro', José Álvaro Pereira Gomes \\ 1. Centro Avançado de Superfície Ocular, Departamento de Oftalmologia e Ciências Visuais, Universidade Federal de São Paulo, São Paulo, SP, Brasil.
}

\begin{abstract}
The transparency and maintenance of corneal epithelial integrity are essential for its optical properties and, to preserve these characteristics, the epithelium undergoes continuous renewal. This renewal depends on the control of cell proliferation and differentiation mediated by mitogenic factors responsible for increasing mitoses and stimulating cellular migration. Cell-cell communication plays a pivotal role in epithelial healing process, and several cytokines and growth factors are involved in this process. Understanding the cross-talk and paracrine effects of these cytokines and growth factors released can help in the search for new therapeutic strategies to treat ocular surface diseases.
\end{abstract}

Keywords: Endothelium, corneal; Cytokines; Wound healing; Cell proliferation

RESUMO | A transparência e a manutenção da integridade epitelial da córnea são essenciais para suas propriedades ópticas e, para preservar tais características, o epitélio sofre renovação contínua. Essa renovação depende do controle da proliferação e diferenciação celular mediadas por fatores mitogênicos responsáveis pelo aumento das mitoses e estímulo à migração celular. A comunicação célula-célula desempenha um papel fundamental no processo de cicatrização epitelial, e várias citocinas e fatores de crescimento estão envolvidos neste processo. Compreender os efeitos cruzados e paracrinos dessas citocinas e fatores de crescimento liberados pode ajudar na busca de novas estratégias terapêuticas para o tratamento de doenças da superfície ocular.

Descritores: Epitélio posterior; Citocinas; Cicatrização; Proliferação celular
Submitted for publication: February 26, 2018

Accepted for publication: July 20, 2018

Funding: No specific financial support was available for this study.

Disclosure of potential conflicts of interest: None of the authors have any potential conflicts of interest to disclose.

Corresponding author: Renata Ruoco Loureiro

Centro Avançado de Superfície Ocular (CASO). Departamento de Oftalmologia e Ciências Visuais. Universidade Federal de São Paulo. Rua Pedro de Toledo, 669

4aandar - São Paulo, SP - 04023-062 - Brasil - E-mail: renata.ruoco@hotmail.com

\section{INTRODUCTION}

The cornea is a specialized tissue that acts as a protective ocular barrier and serves as one of the main refractive elements of the visual system, which together with the lens, refracts appropriately the incident light to the retina ${ }^{(1)}$. The corneal epithelium undergoes constant renewal, which is performed by a population of stem cells (SCs) located in the limbus epithelium ${ }^{(2,3)}$. Several pathological conditions can change the ocular surface and thus affect its functions, and the appropriate reconstruction of the cornea is vital to maintain its transparency and preserve vision ${ }^{(4)}$.

The healing process involves a wide variety of mechanisms, including cell migration and proliferation, which is controlled by cytokines and growth factors (GFs) acting in a paracrine manner in distinct layers of the cornea. The integrated understanding of such mechanisms may help to increase the search for new therapeutic strategies. This article discusses the importance of the mechanisms and processes involved in the biological modulation of corneal epithelial healing as well as the potential therapeutic application of GFs and cytokines to treat ocular surface diseases.

\section{Corneal stem cells}

In an adult organism, many tissues undergo continuous cell renewal. SCs are defined as any cell with high self-renewal capacity, able to repopulate and maintain tissue integrity and responsible for continuous cell renewal ${ }^{(5,6)}$.

Adult SCs became more specialized and are present in anatomically specific tissue sites requiring regeneration. These cells have characteristics such as self-renewal, where, during cell replication, the population of SCs that was lost during the progeny is replaced; permanence in the undifferentiated stage, but with a high potential for differentiation in all cell types of their original tissue and, perhaps, in other cell types; a high ability to 
maintain a stable genotype during cell replication; a slow cell cycle, where most of the time the cells are in a slow stage of growth (however, they can give rise to progeny by highly proliferative differentiation); and they reside in a microenvironment, known as a niche, that provides external factors necessary to keep the SCs properties and functions, known as stemness ${ }^{(7-9)}$.

The maintenance of the corneal epithelium is determined by a distinct population of unipotent SCs, which reside in the basal layer of the limbic corneal-scleral epithelium ${ }^{(4,10)}$. These cells simultaneously maintain their capacity for self-renewal and a constant number, giving rise to rapidly dividing progenitor cells, called transient amplifying cells (TACs), which proliferate and differentiate into post-mitotic corneal epithelium ${ }^{(11)}$.

Located in the limbal stroma are the palisades of Vogt, which are considered to be the niche for maintaining limbal epithelial stemness ${ }^{(12)}$. The fibroblasts in the niche send several signals that control the cellular destination. These signals can be divided into three broad categories: (i) secretion of factors; (ii) cell-cell interactions; and (iii) extracellular interactions ${ }^{(8,13,14)}$. The palisades of Vogt also have anatomical and functional dimensions characterized by numerous undulations. It is assumed that these papillae allow interactions between the limbal basal cells and a vascular system that provides many nutrients, thereby allowing a greater surface area and a high concentration of SCs within a small area ${ }^{(12,15)}$. Several investigations have demonstrated the clonogenic ability of corneal cells, where the central cells mostly generate terminal colonies, known as paraclones, which have limited proliferative activity. Peripheral corneal cells form colonies whose growth breaks after relatively small and rapid divisions, known as meroclones or also as TACs. However, the limbus cells form holoclones, which also have the capacity of self-renewal and high proliferation for many generations ${ }^{(2,16,17)}$.

The presence and absence of morphological characteristics, gene, and protein expression are used to identify the SCs, TACs, and populations of differentiated cells. Adult limbal SCs are morphologically small, with a high nucleus-cytoplasm ratio. The size and content of nuclear deoxyribonucleic acid are constant, but the volume of cytoplasm is altered with new proteins that appear in the process of cell differentiation. Recent studies indicate that smaller cells $(10-16 \mu \mathrm{m})$ have a higher clonogenic capacity in cell culture ${ }^{(18)}$. In addition, limbal cells have a high-level expression of messenger ribonucleic acid and protein markers for SCs, such as p63 and ATP-binding cassette $2^{(9,18,19)}$. Recently, Ksander et al. demonstrated the positive expression of the ATP-binding cassette subfamily B, member 5 , until then identified only in epidermal progenitor cells, associated with limbal SCs ${ }^{(20)}$.

\section{Corneal renewal and wound healing}

According to the theory XYZ, proposed by Thoft et al., the limbus consists of a group of epithelial and SCs cells distributed in layers (cells of Langerhans and melanocytes) that participates in the renovation and maintenance of the cornea through centripetal cell migration. Initially, the cells move through the deeper layers of the epithelium (X) and, as they approach the central region of the cornea, they become more differentiated and elevate to superficial stages $(\mathrm{Y})$ until they complete their life cycle between 5 and 7 days and then detach $(Z)^{(21)}$.

Due to the high resistance of the junctions between epithelial cells, the cornea acts as a physical barrier responsible for protecting the eye $\mathrm{e}^{(3,22)}$. Any damage to the corneal epithelium can activate a series of GFs and cytokines, which are responsible for cellular interactions that heal and renew the affected area ${ }^{(17,22)}$.

Corneal epithelial wound healing occurs via cell proliferation and migration ${ }^{(5,23)}$. Initially, cellular reorganization and protein synthesis occur, causing the loss of structures responsible for cell adhesion, such as desmosomes, hemidesmosomes, and collagen type Vll fibers ${ }^{(23-25)}$. This creates a provisional complex of adhesion, known as focal contacts. The cells assume a flattened morphology and migrate to cover the wound. Subsequently, the distal cells proliferate and migrate to repopulate the wound area, followed by cell stratification and differentiation ${ }^{(26)}$. Finally, the cell adhesion structures are remodeled, and extracellular matrix (ECM) is synthesized ${ }^{(22,27,28)}$.

During the process of epithelial renewal and repair, the secretion of ECM components is altered, influencing the expression of matrix metalloproteinases (MMPs) ${ }^{(29-31)}$. MMPs belong to the extracellular endoproteinase family and, under physiological conditions, are responsible for catalyzing ECM molecules, such as collagen, proteoglycans, and fibronectin, helping to maintain the structure and functions of the cornea ${ }^{(32)}$.

The expression and performance of MMPs are regulated by GFs and cytokines, such as interleukin-1 (IL-1) and transforming growth factor beta (TGF- $\beta$ ), enabling cell migration and tissue repair success ${ }^{(33,34)}$. One example of this process is the elevated expression of MMP-2 and MMP-9 following an epithelial injury, resulting in the migration of keratocytes ${ }^{(32,34,35)}$. 
Chan et al. showed that after a corneal injury, the presence of MMP12 (a macrophage metalloproteinase) has a protective effect against fibrosis, in addition to its contribution in recruiting inflammatory cells, and a negative influence on the angiogenesis process ${ }^{(36)}$. Thus, proper regulation of MMP expression might be an important mechanism to determine the quality of corneal healing ${ }^{(33)}$.

\section{Paracrine effect and cells cross-talk: the role of GFs and cytokines}

The communication between SCs and their niche is the key to corneal epithelial wound healing ${ }^{(37)}$. This cross-talk may involve (i) cell communication, (ii) cell-matrix contact, (iii) paracrine factors, and their receptors ${ }^{(12)}$. These cellular interactions are not exclusive, and some actions may be dependent on or mediated by the expression of other factors ${ }^{(38)}$. Several cytokines and GFs, responsible for cellular communication, are related to the process of epithelial healing. Corneal injuries cause the release of cytokines that act on SCs, which in turn begin to proliferate and differentiate, releasing GFs and repairing the damaged area ${ }^{(39,40)}$.

Using reverse transcriptase polymerase chain reaction and immunostaining techniques, $\mathrm{Li}$ and Tseng have demonstrated that a complex of cytokines and GFs exists between the human corneal and limbus epithelium and fibroblasts. Based on the patterns of positively expressed cytokines/GFs and their receptors, four patterns have been described and classified: type I includes TGF- $\alpha$, IL-1, and platelet-derived growth factor (PDGF), which are expressed exclusively by epithelial cells, but their respective receptors, epidermal growth factor receptor (EGFR), IL-1 receptor (IL-1R), and PDGF receptor (PDGFR), are expressed exclusively by fibroblasts. Type Il includes insulin-like growth factor-l (IGF-l), TGF- $\beta$, leukemia inhibitory factor (LIF), and basic fibroblast growth factor (bFGF), whose cytokines and receptors are expressed by both epithelial and fibroblast cells. Type III includes keratinocyte growth factor (KGF) and hepatocyte growth factor (HGF), which are expressed exclusively by fibroblasts, and their respective receptors, KGF receptor and HGF receptor, are predominantly expressed by epithelial cells. Type IV includes macrophage colony-stimulating factor and IL-8, which are expressed by fibroblasts and/or epithelial cells, but their receptors are expressed by immunological or inflammatory cells $s^{(38,41,42)}$. The division of cytokines and GFs with their respective receptors and actions can be found in table 1 .
Table 1. Different cytokines and growth factors, types, secretion, site of action, and function

\begin{tabular}{|c|c|c|c|c|}
\hline $\begin{array}{l}\text { Cytokine and } \\
\text { growth factors }\end{array}$ & Type & Secretion & Receptor & Function \\
\hline $\begin{array}{l}\text { TGF- } \alpha \\
\text { (related to EGF }\end{array}$ & l & Epithelium & Fibroblasts & $\begin{array}{c}\text { Secreted by } \\
\text { proliferative } \\
\text { healthy cells. } \\
\text { Induces } \\
\text { epithelial growth }\end{array}$ \\
\hline IL-1 & l & Epithelium & Fibroblasts & $\begin{array}{c}\text { Secreted } \\
\text { in stress or } \\
\text { apoptosis. } \\
\text { Stimulates } \\
\text { secretion of type } \\
\text { ll cytokines }\end{array}$ \\
\hline PDGF & l & Epithelium & Fibroblasts & $\begin{array}{l}\text { Along TGF } \alpha \\
\text { stimulate the } \\
\text { proliferation } \\
\text { of fibroblasts } \\
\text { and induces } \\
\text { extracellular } \\
\text { matrix synthesis } \\
\text { promoting } \\
\text { healing }\end{array}$ \\
\hline IGF-I & Il & $\begin{array}{l}\text { Epithelium } \\
\text { and } \\
\text { fibroblasts }\end{array}$ & $\begin{array}{l}\text { Epithelium } \\
\text { and } \\
\text { fibroblasts }\end{array}$ & $\begin{array}{c}\text { Promotes } \\
\text { migration and } \\
\text { production of } \\
\text { extracellular } \\
\text { matrix }\end{array}$ \\
\hline TGF- $\beta$ & Il & $\begin{array}{l}\text { Epithelium } \\
\text { and } \\
\text { fibroblasts }\end{array}$ & $\begin{array}{l}\text { Epithelium } \\
\text { and } \\
\text { fibroblasts }\end{array}$ & $\begin{array}{c}\text { Promotes } \\
\text { differentiation } \\
\text { and inhibits } \\
\text { proliferation }\end{array}$ \\
\hline LIF & Il & $\begin{array}{l}\text { Epithelium } \\
\text { and } \\
\text { fibroblasts }\end{array}$ & $\begin{array}{l}\text { Epithelium } \\
\text { and } \\
\text { fibroblasts }\end{array}$ & $\begin{array}{c}\text { Inhibits } \\
\text { differentiation }\end{array}$ \\
\hline bFGF & ll & $\begin{array}{l}\text { Epithelium } \\
\text { and } \\
\text { fibroblasts }\end{array}$ & $\begin{array}{l}\text { Epithelium } \\
\text { and } \\
\text { fibroblasts }\end{array}$ & $\begin{array}{l}\text { Promotes } \\
\text { fibroblasts } \\
\text { growth }\end{array}$ \\
\hline KGF & Ill & Fibroblasts & Epithelium & $\begin{array}{l}\text { Increases stem } \\
\text { cells division }\end{array}$ \\
\hline HGF & Ill & Fibroblasts & Epithelium & $\begin{array}{c}\text { Production and } \\
\text { migration of } \\
\text { TACs }\end{array}$ \\
\hline M-CSF & IV & $\begin{array}{l}\text { Epithelium } \\
\text { and } \\
\text { fibroblasts }\end{array}$ & $\begin{array}{c}\text { Immune or } \\
\text { inflammatory } \\
\text { cells }\end{array}$ & $\begin{array}{l}\text { Promotes the } \\
\text { macrophages } \\
\text { recruitment }\end{array}$ \\
\hline IL-8 & IV & $\begin{array}{l}\text { Epithelium } \\
\text { and } \\
\text { fibroblasts }\end{array}$ & $\begin{array}{c}\text { Immune or } \\
\text { inflammatory } \\
\text { cells }\end{array}$ & $\begin{array}{c}\text { Positively } \\
\text { regulated } \\
\text { by } \mathrm{M}-\mathrm{CSF} \text { in } \\
\text { inflammatory } \\
\text { processes }\end{array}$ \\
\hline
\end{tabular}

TGF- $\alpha=$ transforming growth factor alpha; $\mathrm{EGF}=$ epidermal growth factor; $\mathrm{IL}-1=$ interleukin 1 ; $\mathrm{PDGF}=$ platelet-derived growth factor; $\mathrm{IGF}=$ insulin-like growth factor; $\mathrm{LIF}=$ leukemia inhibitory factor; $\mathrm{bFGF}=$ basic fibroblast growth factor; $\mathrm{KGF}=$ keratinocyte growth factor; $\mathrm{HGF}=$ hepatocyte growth factor; $\mathrm{M}-\mathrm{CSF}=$ macrophage colony-stimulating factor, $\mathrm{IL}-8=$ interleukin 8 .

Following an epithelial injury, keratocyte death by apoptosis ensues in the central stroma. Keratocyte apoptosis may affect $25-50 \%$ of stromal thickness depending 
on the type of lesion. This mechanism of stromal modification may be associated with the organism's response to delay the pathogen's range $\mathrm{e}^{(37,43)}$.

Some studies suggest that factors secreted by the corneal epithelium, such as IL-1 and tumor necrosis factor alpha (TNF- $\alpha$ ), directly or indirectly modulate keratocyte apoptosis. However, it is not possible to say definitively that epithelial modulators penetrate fully into the stroma, but probably the apoptotic signals received by superficial keratocytes are transmitted through cell-cell interactions to the deeper stromal cells ${ }^{(37,43-45)}$.

Another important cellular interaction in corneal healing involves the recruitment of inflammatory cells into the stroma. Monocytes, granulocytes, T lymphocytes, and other inflammatory cells migrate into the corneal stroma a few hours after an epithelial injury or a corneal infection ${ }^{(46,47)}$. When this happens, the epithelial release of IL-1 and TNF- $\alpha$ induces the production of monocyte chemotactic activator factor and granulocyte colony-stimulating factor by keratocytes, which attracts the inflammatory cells into the stroma ${ }^{(44,48)}$.

As the healing processes occur, the stromal cells are replaced by proliferation, migration, and differentiation of the remaining keratocytes. This action is mediated by cytokine/GF type I and II, released by the corneal epithelium, including PDGF, which is responsible for the replacement of keratocytes, and TGF- $\beta$, which acts to differentiate the keratocytes into myofibroblasts ${ }^{(46,49)}$.

In the cytokine/GF type I, TGF- $\alpha$ can be related to epidermal growth factor (EGF) because they are considered homologous and have the same receptor (EGFR). Both factors exert similar mitogenic actions, but TGF- $\alpha$ appears to be more potent and induces neovascularization, cell migration, and increased blood flow ${ }^{(1,38,41,42)}$. EGF can be found in the tear film, whereas TGF- $\alpha$ is secreted by the corneal epithelium. On corneal injury, the EGF already present in the tear film can act immediately on the corneal epithelium, inducing cell proliferation ${ }^{(3,38)}$.

TGF- $\alpha$ and EGF stimulate the expression of LIF and HGF by corneal fibroblasts, increasing the migration of TACs, and decreasing KGF expression by limbal fibroblasts, attenuating the proliferation of SCs. Furthermore, TGF- $\alpha$ increases fibroblast expression of TGF- $\beta$ and PDGFRs, causing a better response to PDGF stimulation that acts synergistically with TGF- $\beta$ activating the proliferation of stromal fibroblasts ${ }^{(38,42,50)}$.

$\mathrm{Li}$ and Tseng observed that KGF is expressed to a higher degree by limbal fibroblasts, while the higher expression of HGF is found within corneal fibroblasts. Such differences in the expression of KGF and HGF by limbus or corneal fibroblasts may exist because KGF is involved in the function and proliferation of SCs, and HGF acts on TACs ${ }^{(42)}$.

KGF and HGF are regulated in different ways by cytokine/GF type $\mathbf{l}^{(51)}$. When an epithelial lesion occurs, IL-1 secretion stimulates KGF production by limbal fibroblasts, activating the division of SCs. However, during the healing process, cytokine/GF type I is secreted by the corneal epithelium to stimulate HGF production by corneal fibroblasts, and thus acts on the proliferation and migration of TACs to renew the corneal epithelium ${ }^{(31,41,42)}$.

The expression of KGF and HGF is down-regulated by cytokine/GF type Il, especially TGF- $\beta$. This inhibition pathway may indicate that cell division is no longer required by limbus cells ${ }^{(31,41)}$.

\section{Therapeutic use of GF/cytokines in ocular surface diseases}

After noting the crucial importance of cross-talk and paracrine effects on cell migration, proliferation, and differentiation $^{(52,53)}$, several authors have been investigating alternatives to improve the cultivation and cell maintenance in vitro, aiming for cell therapy, or analyzing the effectiveness of a conditioned medium (CM) as a noninvasive therapy $^{(54,55)}$. We can define a $\mathrm{CM}$ as a culture medium that contains biologically active components produced by the cells themselves. The CM may contain metabolites, GFs, and ECM proteins secreted in the medium by the cultured cells.

Importantly, some studies have shown that cells can recover specific functions by controlling their microenvironment in vitro. Differentiated cells treated with a CM from progenitor cells or SCs improved their proliferation rate significantly, decreased apoptosis levels, and could maintain their original phenotype ${ }^{(56-58)}$.

The cytokines and GFs present in a CM can also act on mesenchymal cells, directing their differentiation line. Park et al. demonstrated the differentiation of mesenchymal SCs into corneal keratocyte-like cells when treated with a keratocyte $\mathrm{CM}$. These findings enable the development of new strategies using cell therapy for corneal renewal using differentiated mesenchymal SCs derived from bone marrow ${ }^{(59)}$. Amirjamshidi et al. verified that the CM from human limbal fibroblast may have a beneficial therapeutic effect in the treatment of limbal SC deficiency in an experimental mouse model. They observed that topical therapy with the CM promoted the corneal epithelial phenotype, with a concomitant decrease in 
corneal conjunctivalization. These findings can be attributed to the action of the GFs present in the $\mathrm{CM}^{(40)}$.

Another source of the potential application of GFs/ cytokines are the compounds of the amniotic membrane (AM), a relevant tissue used widely in ophthalmology to control inflammation and promote wound healing on the ocular surface ${ }^{(60)}$. Lee et al. and Bischoff et al. have identified the presence of GFs/cytokines in the $\mathrm{CM}$ obtained from the AM. They found IGF(61), EGF, bFGF, IL-6, and IL-8 ${ }^{(62)}$ in AM-CM and observed an increased proliferation of human corneal epithelial cells when treated with such a CM. Kim et al. demonstrated that the use of CM from human AM epithelial cells exerts positive effects on wound healing in an experimental rabbit model with a corneal alkaline injury ${ }^{(63)}$. These outcomes were considered as a potential alternative for non-surgical treatment in cases of corneal epithelial defects ${ }^{(61-63)}$.

Several studies have demonstrated the effects of a lyophilized form of AM, known as "amniotic membrane extract” (AME). Jiang et al. showed that AME inhibits the neovascularization induced by a chemical burn ${ }^{(64)}$. Liang et al. demonstrated the benefits of AME for ocular chemical burns with a preliminary study demonstrating its ability to reduce corneal inflammation and promote re-epithelization ${ }^{(65)}$. Dudok et al. used AME to treat corneal and limbal epithelial cells under mechanical stress, which healed faster ${ }^{(66)}$. Collectively, these results suggests the potential benefit of AME for the treatment of acute corneal injuries. Most recently, Baradaran-Rafii et al. evaluated the outcomes of a surgical technique supplemented with "amniotic membrane extract eye drops" (AMEED) for the in vivo cultivation of limbal SCs. Patients with unilateral total limbal stem cell deficiency (LSCD) had the cornea covered by a cryopreserved AM, and then one small limbal piece collected from the contralateral healthy eye was transferred to the diseased eye. The patients were divided into case and control groups, and AMEED was administered postoperatively only for patients in the case group. In the case group, all eyes showed an improvement in visual acuity, the epithelial defects healed, and corneal conjunctivalization decreased dramatically. Conversely, in the control group, all eyes had a persistent epithelial defect. These outcomes suggest that additional treatment with AMEED promoted the in vivo cultivation of limbal SCs probably due to the GFs/cytokines present in the eye drops ${ }^{(67)}$.

It is important to mention a matrix component termed heavy chain (HC)-hyaluronan (HA)/pentraxin 3 (PTX3), produced endogenously by the AM. Tseng et al. purified the HC-HA/PTX3 complex from AME and showed its anti-inflammatory, anti-scarring, and anti-angiogenic effects. He also demonstrated that the HC-HA/PTX3 complex maintains limbal niche cells by supporting the quiescent SCs. These findings suggest that this complex can be useful in restoring the limbal niche as a new strategy to treat $\mathrm{LSCD}^{(68-70)}$.

The use of topical fibronectin has already been reported to improve the corneal healing process ${ }^{(71,72)}$. The presence of fibronectin was not identified in the CM or the AM. However, it can be obtained from blood plasma, and its paracrine effect was observed in corneal epithelial cells ${ }^{(73)}$. Nishida et al. showed that the administration of fibronectin eyedrops facilitated corneal epithelial wound healing in rabbits ${ }^{(74)}$ and Nakamura et al. observed the same effect in diabetic rats, which demonstrates a delayed corneal reconstruction ${ }^{(75)}$. The main effect of fibronectin on epithelial healing may be related to increased cell adhesion and migration, acting as a provisional ECM during corneal renewal.

Some years ago, scientists showed the involvement of nerve growth factor (NGF) in the proliferation and differentiation of the corneal epithelium ${ }^{(76)}$. Since this discovery, several studies have been conducted using the topical application of NGF to treat inflammatory and epithelial defects on the ocular surface ${ }^{(77,78)}$. Lambiase et al. demonstrated through in vitro and in vitro studies that NGF plays a role in corneal epithelium-stroma communication. This GF induces both stromal and epithelial healing, and it also restores corneal sensitivity, with no local or systemic side effects in patients with a neurotropic corneal ulcer ${ }^{(79,80)}$.

\section{FINAL CONSIDERATIONS}

The expression of many cytokines and GFs are associated with corneal cell maintenance and healing. Understanding these mechanisms is becoming increasingly important, and is imperative to facilitate the development of efficient therapeutic strategies.

Recent studies have demonstrated that the use of cell therapy may be a potential treatment modality for a variety of diseases, and its success depends largely on the number of transplanted cells, their adherence, and post-transplant survival. During the period in which the cells remained active, cytokines and GFs were observed on the injured tissue, evidence of the paracrine effect and cross-talk between the corneal cells.

Based on these findings, promising clinical studies using the application or inducing the production of cytokines and GFs as noninvasive therapy options are underway, aiming to restore the corneal homeostasis of different ocular surface diseases. 


\section{REFERENCES}

1. Yu FS, Yin J, Xu K, Huang J. Growth factors and corneal epithelial wound healing. Brain Res Bull. 2010;81(2-3):229-35.

2. Pellegrini G, Rama P, Mavilio F, De Luca M. Epithelial stem cells in corneal regeneration and epidermal gene therapy. J Pathol. 2009; 217(2):217-28.

3. Reinach PS, Pokorny KS. The corneal epithelium: clinical relevance of cytokine-mediated responses to maintenance of corneal health. Arq Bras Oftalmol. 2008;71(6 Suppl):80-6.

4. Lindberg K, Brown ME, Chaves HV, Kenyon KR, Rheinwald JG. In vitro propagation of human ocular surface epithelial cells for transplantation. Invest Ophthalmol Vis Sci. 1993 Aug;34(9):2672-9.

5. Zieske JD. Perpetuation of stem cells in the eye. Eye (Lond). 1994; 8(Pt 2):163-9.

6. Blazejewska EA, Schlötzer-Schrehardt U, Zenkel M, Bachmann B, Chankiewitz E, Jacobi C, et al. Corneal limbal microenvironment can induce transdifferentiation of hair follicle stem cells into corneal epithelial-like cells. Stem Cells. 2009;27(3):642-52.

7. Alison MR, Poulsom R, Forbes S, Wright NA. An introduction to stem cells. J Pathol. 2002;197(4):419-23.

8. O'Sullivan F, Clynes M. Limbal stem cells, a review of their identification and culture for clinical use. Cytotechnology. 2007;53(1-3): 101-6.

9. Takács L, Tóth E, Berta A, Vereb G. Stem cells of the adult cornea: from cytometric markers to therapeutic applications. Cytometry A. 2009;75(1):54-66.

10. Lu R, Bian F, Zhang X, Qi H, Chuang EY, Pflugfelder SC, et al. The $\beta$-catenin/Tcf4/survivin signaling maintains a less differentiated phenotype and high proliferative capacity of human corneal epithelial progenitor cells. Int J Biochem Cell Biol. 2011;43(5):751-9.

11. Lehrer MS, Sun TT, Lavker RM. Strategies of epithelial repair: modulation of stem cell and transit amplifying cell proliferation. J Cell Sci. 1998;111(19):2867-75.

12. Li W, Hayashida Y, Chen YT, Tseng SC. Niche regulation of corneal epithelial stem cells at the limbus. Cell Res. 2007;17(1):26-36.

13. Du Y, Chen J, Funderburgh JL, Zhu X, Li L. Functional reconstruction of rabbit corneal epithelium by human limbal cells cultured on amniotic membrane. Mol Vis. 2003;9:635-43.

14. Pinnamaneni N, Funderburgh JL. Concise review: stem cells in the corneal stroma. Stem Cells. 2012;30(6):1059-63.

15. Di Girolamo N. Stem cells of the human cornea. Br Med Bull. 2011; 100(1):191-207.

16. Barrandon Y, Green H. Three clonal types of keratinocyte with different capacities for multiplication. Proc Natl Acad Sci USA. 1987;84(8):2302-6.

17. Castro-Muñozledo F. Review: corneal epithelial stem cells, their niche and wound healing. Mol Vis. 2013;19:1600-13.

18. De Paiva CS, Pflugfelder SC, Li DQ. Cell size correlates with phenotype and proliferative capacity in human corneal epithelial cells. Stem Cells. 2006;24(2):368-75.

19. Dua HS, Shanmuganathan VA, Powell-Richards AO, Tighe PJ, Joseph A. Limbal epithelial crypts: a novel anatomical structure and a putative limbal stem cell niche. Br J Ophthalmol. 2005;89(5):529-32.

20. Ksander BR, Kolovou PE, Wilson BJ, Saab KR, Guo Q, Ma J, et al. $A B C B 5$ is a limbal stem cell gene required for corneal development and repair. Nature. 2014;511(7509):353-7.

21. Thoft RA, Friend J. The X, Y, Z hypothesis of corneal epithelial maintenance. Invest Ophthalmol Vis Sci. 1983;24(10):1442-3.

22. Agrawal VB, Tsai RJ. Corneal epithelial wound healing. Indian J Ophthalmol. 2003;51(1):5-15.

23. Okada Y, Saika S, Shirai K, Hashizume N, Yamanaka O, Ohnishi $\mathrm{Y}$, et al. Disappearance of desmosomal components in rat corneal epithelium during wound healing. Ophthalmologica Journal inter- national d'ophtalmologie International journal of ophthalmology. Z Augenheilkd. 2001;215(1):61-5.

24. Gipson IK, Spurr-Michaud S), Tisdale AS. Anchoring fibrils form a complex network in human and rabbit cornea. Invest Ophthalmol Vis Sci. 1987;28(2):212-20.

25. Klatte DH, Kurpakus MA, Grelling KA, Jones JC. Immunochemical characterization of three components of the hemidesmosome and their expression in cultured epithelial cells. J Cell Biol. 1989;109(6 Pt 2):3377-90.

26. Crosson CE, Klyce SD, Beuerman RW. Epithelial wound closure in the rabbit cornea. A biphasic process. Invest Ophthalmol Vis Sci. 1986;27(4):464-73.

27. Panjwani N, Michalopoulos G, Song J, Zaidi TS, Yogeeswaran G, Baum J. Neutral glycolipids of migrating and nonmigrating rabbit corneal epithelium in organ and cell culture. Invest Ophthalmol Vis Sci. 1990;31(4):689-95.

28. Zieske JD, Gipson IK. Protein synthesis during corneal epithelial wound healing. Invest Ophthalmol Vis Sci. 1986;27(1):1-7.

29. Li DQ, Lokeshwar BL, Solomon A, Monroy D, Ji Z, Pflugfelder SC. Regulation of MMP-9 production by human corneal epithelial cells. Exp Eye Res. 2001;73(4):449-59.

30. Sivak JM, Fini ME. MMPs in the eye: emerging roles for matrix metalloproteinases in ocular physiology. Prog Retin Eye Res. 2002; 21(1):1-14.

31. Wilson SE, Mohan RR, Mohan RR, Ambrósio R Jr, Hong J, Lee J. The corneal wound healing response: cytokine-mediated interaction of the epithelium, stroma, and inflammatory cells. Prog Retin Eye Res. 2001;20(5):625-37.

32. Chang JH, Huang YH, Cunningham CM, Han KY, Chang M, Seiki M, et al. Matrix metalloproteinase 14 modulates signal transduction and angiogenesis in the cornea. Surv Ophthalmol. 2016;61(4):478-97.

33. Girard MT, Matsubara M, Fini ME. Transforming growth factor-beta and interleukin-1 modulate metalloproteinase expression by corneal stromal cells. Invest Ophthalmol Vis Sci. 1991;32(9):2441-54.

34. Yang YH, Hsieh TL, Ji AT, Hsu WT, Liu CY, Lee OK, et al. Stromal Tissue Rigidity Promotes Mesenchymal Stem Cell-Mediated Corneal Wound Healing Through the Transforming Growth Factor $\beta$ Signaling Pathway. Stem Cells. 2016;34(10):2525-35.

35. Petznick A, Madigan MC, Garrett Q, Sweeney DF, Evans MD. Contributions of ocular surface components to matrix-metalloproteinases (MMP)-2 and MMP-9 in feline tears following corneal epithelial wounding. PLoS One. 2013;8(8):e71948.

36. Chan MF, Li J, Bertrand A, Casbon AJ, Lin JH, Maltseva I, et al. Protective effects of matrix metalloproteinase-12 following corneal injury. J Cell Sci. 2013;126(17):3948-60.

37. Wilson SE, Netto M, Ambrósio R Jr. Corneal cells: chatty in development, homeostasis, wound healing, and disease. Am J Ophthalmol. 2003;136(3):530-6.

38. Li DQ, Tseng SC. Differential regulation of cytokine and receptor transcript expression in human corneal and limbal fibroblasts by epidermal growth factor, transforming growth factor-alpha, platelet-derived growth factor B, and interleukin-1 beta. Invest Ophthalmol Vis Sci. 1996;37(10):2068-80.

39. Imanishi J, Kamiyama K, Iguchi I, Kita M, Sotozono C, Kinoshita S. Growth factors: importance in wound healing and maintenance of transparency of the cornea. Prog Retin Eye Res. 2000;19(1):113-29.

40. Amirjamshidi H, Milani BY, Sagha HM, Movahedan A, Shafiq MA, Lavker RM, et al. Limbal fibroblast conditioned media: a non-invasive treatment for limbal stem cell deficiency. Mol Vis. 2011;17:658-66.

41. Daniels JT, Dart JK, Tuft SJ, Khaw PT. Corneal stem cells in review. Wound repair and regeneration: official publication of the Wound Healing Society [and] the European Tissue Repair Society. Wound Repair Replac. 2001;9(6):483-94.

42. Li DQ, Tseng SC. Differential regulation of keratinocyte growth factor and hepatocyte growth factor/scatter factor by different cytokines 
in human corneal and limbal fibroblasts. J Cell Physiol. 1997; 172(3):361-72.

43. Wilson SE, Kim WJ. Keratocyte apoptosis: implications on corneal wound healing, tissue organization, and disease. Invest Ophthalmol Vis Sci. 1998;39(2):220-6.

44. Hong JW, Liu JJ, Lee JS, Mohan RR, Mohan RR, Woods DJ, et al. Proinflammatory chemokine induction in keratocytes and inflammatory cell infiltration into the cornea. Invest Ophthalmol Vis Sci. 2001;42(12):2795-803.

45. Wilson SE, Pedroza L, Beuerman R, Hill JM. Herpes simplex virus type-1 infection of corneal epithelial cells induces apoptosis of the underlying keratocytes. Exp Eye Res. 1997;64(5):775-9.

46. Mohan RR, Hutcheon AE, Choi R, Hong J, Lee J, Mohan RR, et al. Apoptosis, necrosis, proliferation, and myofibroblast generation in the stroma following LASIK and PRK. Exp Eye Res. 2003;76(1):71-87.

47. O'Brien TP, Li Q, Ashraf MF, Matteson DM, Stark WJ, Chan CC. Inflammatory response in the early stages of wound healing after excimer laser keratectomy. Arch Ophthalmol. 1998;116(11):1470-4.

48. Wilson SE, Schultz GS, Chegini N, Weng J, He YG. Epidermal growth factor, transforming growth factor alpha, transforming growth factor beta, acidic fibroblast growth factor, basic fibroblast growth factor, and interleukin-1 proteins in the cornea. Exp Eye Res. 1994;59(1):63-71.

49. Jester JV, Petroll WM, Cavanagh HD. Corneal stromal wound healing in refractive surgery: the role of myofibroblasts. Prog Retin Eye Res. 1999;18(3):311-56.

50. Dravida S, Pal R, Khanna A, Tipnis SP, Ravindran G, Khan F. The transdifferentiation potential of limbal fibroblast-like cells. Brain Res Dev Brain Res. 2005;160(2):239-51.

51. Wilson SE, Walker JW, Chwang EL, He YG. Hepatocyte growth factor, keratinocyte growth factor, their receptors, fibroblast growth factor receptor-2, and the cells of the cornea. Invest Ophthalmol Vis Sci. 1993;34(8):2544-61.

52. Ebato B, Friend J, Thoft RA. Comparison of limbal and peripheral human corneal epithelium in tissue culture. Invest Ophthalmol Vis Sci. 1988;29(10):1533-7.

53. Pellegrini G, Golisano O, Paterna P, Lambiase A, Bonini S, Rama $\mathrm{P}$, et al. Location and clonal analysis of stem cells and their differentiated progeny in the human ocular surface. J Cell Biol. 1999; 145(4):769-82.

54. Burlacu A, Grigorescu G, Rosca AM, Preda MB, Simionescu M. Factors secreted by mesenchymal stem cells and endothelial progenitor cells have complementary effects on angiogenesis in vitro. Stem Cells Dev. 2013;22(4):643-53.

55. Cheng AS, Yau TM. Paracrine effects of cell transplantation: strategies to augment the efficacy of cell therapies. Semin Thorac Cardiovasc Surg. 2008;20(2):94-101.

56. Liu Y, Ding Y, Ma P, Wu Z, Duan H, Liu Z, et al. Enhancement of long-term proliferative capacity of rabbit corneal epithelial cells by embryonic stem cell conditioned medium. Tissue Eng Part C Methods. 2010;16(4):793-802.

57. Lu X, Chen D, Liu Z, Li C, Liu Y, Zhou J, et al. Enhanced survival in vitro of human corneal endothelial cells using mouse embryonic stem cell conditioned medium. Mol Vis. 2010;16:611-22.

58. Zhu MY, Yao QK, Chen JZ, Shao CY, Yan CX, Ni N, et al. Effects of corneal stromal cell- and bone marrow-derived endothelial progenitor cell-conditioned media on the proliferation of corneal endothelial cells. Int J Ophthalmol. 2016;9(3):332-9.

59. Park SH, Kim KW, Chun YS, Kim JC. Human mesenchymal stem cells differentiate into keratocyte-like cells in keratocyte-conditioned medium. Exp Eye Res. 2012;101:16-26.

60. Dua HS, Gomes JA, King AJ, Maharajan VS. The amniotic membrane in ophthalmology. Surv Ophthalmol. 2004;49(1):51-77.

61. Lee JH, Ryu IH, Kim EK, Lee JE, Hong S, Lee HK. Induced expression of insulin-like growth factor- 1 by amniotic membrane-conditioned medium in cultured human corneal epithelial cells. Invest Ophthalmol Vis Sci. 2006;47(3):864-72.

62. Bischoff M, Stachon T, Seitz B, Huber M, Zawada M, Langenbucher A, et al. Growth Factor and Interleukin Concentrations in Amniotic Membrane-Conditioned Medium. Curr Eye Res. 2017;42(2):174-80.

63. Kim TH, Park YW, Ahn JS, Ahn JT, Kim SE, Jeong MB, et al. Effects of conditioned media from human amniotic epithelial cells on corneal alkali injuries in rabbits. J Vet Sci. 2013;14(1):61-7.

64. Jiang A, Li C, Gao Y, Zhang M, Hu J, Kuang W, et al. In vivo and in vitro inhibitory effect of amniotic extraction on neovascularization. Cornea. 2006;25(10):S36-40.

65. Liang L, Li W, Ling S, Sheha H, Qiu W, Li C, et al. Amniotic membrane extraction solution for ocular chemical burns. Clin Experiment Ophthalmol. 2009;37(9):855-63.

66. Dudok DV, Nagdee I, Cheung K, Liu H, Vedovelli L, Ghinelli E, et al. Effects of amniotic membrane extract on primary human corneal epithelial and limbal cells. Clin Experiment Ophthalmol. 2015;43(5):443-8.

67. Baradaran-Rafii A, Asl NS, Ebrahimi M, Jabbehdari S, Bamdad S, Roshandel D, et al. The role of amniotic membrane extract eye drop (AMEED) in in vivo cultivation of limbal stem cells. Ocul Surf. 2018;16(1):146-53.

68. Chen SY, Han B, Zhu YT, Mahabole M, Huang J, Beebe DC, et al. HC-HA/PTX3 Purified From Amniotic Membrane Promotes BMP Signaling in Limbal Niche Cells to Maintain Quiescence of Limbal Epithelial Progenitor/Stem Cells. Stem Cells. 2015;33(11):3341-55.

69. Tseng SC. HC-HA/PTX3 Purified From Amniotic Membrane as Novel Regenerative Matrix: Insight Into Relationship Between Inflammation and Regeneration. Invest Ophthalmol Vis Sci. 2016; 57(5):ORSFh1-8.

70. Zhang S, Zhu YT, Chen SY, He H, Tseng SC. Constitutive expression of pentraxin 3 (PTX3) protein by human amniotic membrane cells leads to formation of the heavy chain (HC)-hyaluronan (HA)-PTX3 complex. J Biol Chem. 2014;289(19):13531-42.

71. Nishida T. The role of fibronectin in corneal wound healing explored by a physician-scientist. Jpn J Ophthalmol. 2012;56(5):417-31.

72. Watanabe K, Frangieh G, Reddy CV, Kenyon KR. Effect of fibronectin on corneal epithelial wound healing in the vitamin A-deficient rat. Invest Ophthalmol Vis Sci. 1991;32(7):2159-62.

73. Ding M, Burstein NL. Fibronectin in corneal wound healing. J Ocul Pharmacol. 1988;4(1):75-91.

74. Nishida T, Nakagawa S, Nishibayashi C, Tanaka H, Manabe R. Fibronectin enhancement of corneal epithelial wound healing of rabbits in vivo. Arch Ophthalmol. 1984;102(3):455-6.

75. Nakamura M, Sato N, Chikama T, Hasegawa Y, Nishida T. Fibronectin facilitates corneal epithelial wound healing in diabetic rats. Exp Eye Res. 1997;64(3):355-9.

76. Kruse FE, Tseng SC. Growth factors modulate clonal growth and differentiation of cultured rabbit limbal and corneal epithelium. Invest Ophthalmol Vis Sci. 1993;34(6):1963-76.

77. Lambiase A, Sacchetti M, Bonini S. Nerve growth factor therapy for corneal disease. Curr Opin Ophthalmol. 2012;23(4):296-302.

78. Micera A, Lambiase A, Puxeddu I, Aloe L, Stampachiacchiere B, Levi-Schaffer F, et al. Nerve growth factor effect on human primary fibroblastic-keratocytes: possible mechanism during corneal healing. Exp Eye Res. 2006;83(4):747-57.

79. Lambiase A, Manni L, Bonini S, Rama P, Micera A, Aloe L. Nerve growth factor promotes corneal healing: structural, biochemical, and molecular analyses of rat and human corneas. Invest Ophthalmol Vis Sci. 2000;41(5):1063-9.

80. Lambiase A, Rama P, Bonini S, Caprioglio G, Aloe L. Topical treatment with nerve growth factor for corneal neurotrophic ulcers. N Engl J Med. 1998;338(17):1174-80. 